\title{
The Contestation of Citizenship Education at Three Stages of the LINC 4 \& 5 Curriculum Guidelines: Production, Reception, and Implementation
}

Robert Pinet

This article highlights how citizenship and citizenship education are sites of contestation. I have analyzed the process of curriculum making of the LINC $4 \mathcal{E}$ 5 Curriculum Guidelines (TCDSB, 1999) through three stages: from production, through reception, to implementation. The production stage is investigated by contrasting commentaries from two members of the Advisory or Specialist Committees who helped to prepare the document. The reception stage featured a thematic analysis of the Guidelines. The implementation stage is investigated through interviews with five present or former LINC teachers, who discuss how they used or are using the Guidelines as part of their curriculum-in-use. Although this LINC document can be characterized as representing a "Liberal democratic" approach to citizenship and a transactional approach to citizenship education in a multicultural framework, a minority position supporting a more critical and transformational approach to citizenship education is also evident.

Cet article souligne que la citoyenneté et l'éducation à la citoyenneté sont des notions qui prêtent à la contestation. L'auteur a analysé le développement, en trois étapes, du programme-cadre d'études CLIC 4 et 5 (TCDSB, 1999) : production, accueil et mise en oeuvre. L'étude de l'étape de la production repose sur la comparaison de commentaires de la part de deux membres des comités consultatifs ayant participé à la préparation du document. Celle de l'étape de l'accueil a consisté en une analyse thématique du programme-cadre. Pour l'étape de la mise en oeuvre, l'auteur s'est appuyé sur des entrevues avec cinq enseignants de CLIC (anciens ou actuels) portant sur l'emploi qu'ils faisaient, ou avaient fait, du programme-cadre dans leurs cours. Alors que le document CLIC se caractérise par une approche libérale et démocratique à la citoyenneté et une approche ponctuelle à l'éducation à la citoyenneté dans un cadre multiculturel, une position minoritaire appuyant une approche plus critique et transformationnelle à l'éducation à la citoyenneté s'en dégage également.

\section{Introduction}

Studies of the federally sponsored Language Instruction for Newcomers to Canada (LINC) program have tended to focus on mini-ethnographies of 
small groups of language settlement teachers (Cray, 1997; Cleghorn, 2000; Richardson, 1999) or of textual analysis of citizenship concepts (Thomson \& Derwing, 2004). In this study, I analyze one curricular text from LINC through the three stages of production, reception, and implementation.

I begin by introducing various concepts of citizenship and citizenship education through a literature review. Then I offer a brief history of the federally funded LINC language and settlement program for immigrants. Next, using Miller and Seller's (1990) model of three types of curriculumtransmission, transaction, and transformation-I show how various interpretations of citizenship education inform the production, reception, and implementation stages of the LINC $4 \mathcal{E} 5$ Curriculum Guidelines. Each stage represents a site of conflict in which the formalized descriptors of a taskbased, communicative language document both enable and constrain the types of citizenship practices that might be explored through pedagogy.

The production stage is investigated through data provided by two members of the Expert or Advisory Committees involved in the curriculummaking process, the reception stage through a thematic analysis of the document, and the implementation stage through interviews with five present or former LINC teachers who discuss how they used, modified, or ignored the Guidelines while acting as curriculum-makers in their own LINC classrooms.

\section{Theoretical Framework: Curriculum Metaorientations}

Miller and Seller's (1990) Curriculum: Perspectives and Practice offers a model of three characteristic types of curriculum metaorientations-transmission, transaction, and transformation-which differ in context, aim, learning experience, role of the teacher, and evaluation.

In a transmission curriculum, the context is based on an atomistic paradigm in which reality is broken down into distinct elements. Transmission is linked philosophically to empiricism, psychologically to behaviorism, and politically to conservatism. The aim of transmission is subject mastery and the inculcation of social norms. Students are expected to learn facts and concepts in a structured environment where the teacher plays a directive role and where evaluation is based on traditional achievement tests.

Bobbitt's (1924) education theory of the 1920s and 1930s is a prime example of transmission curriculum (Miller \& Seller, 1990). It is based on the breaking down of subject matter in a school curriculum into small components that mirrored the mechanistic society and sought to shape the individual student to social norms. In How to Make a Curriculum, Bobbitt (1924) stresses practical and conservative aims for education. In a chapter on objectives, he writes, "But merely shifting positions is not necessarily progress. There are more ways of going wrong than of going right. The status quo is usually better than changes in the wrong directions" (p. 7). 
The application of "scientific" principles to increase efficiency (while maintaining the status quo of early 20th-century America) is also apparent in the list of 821 Major Objectives of Education, which take up 19 pages of the third chapter of Bobbitt's book (1924). One of the subsections is devoted to "Efficient Citizenship." Objective 201 reads, "Ability to think, feel, act, and react as an efficient, intelligent, sympathetic and loyal member of the social group - that group that is prior to differentiation and within which social differentiation occurs" (p. 15). By this Bobbitt suggests that loyalties to particular identities should be subsumed in citizenship education to loyalty to the (apolitical or) greater society. Or more particularly, in terms of the citizenship education of immigrants, that they are to lose their ethnic identities in the social melting pot of the United States. The transmission model has been attacked by critical theorists for aiming to conserve and reproduce existing social structures.

A transaction curriculum stresses interaction between the student and the social environment. It is linked psychologically to cognitive developmentalism and politically to liberalism. The aim of a transaction curriculum is to develop rationality and complex problem-solving skills. The learning experiences stress inquiry and the development of both problem-solving skills and "inquiry skills that facilitate democratic decision making" (Miller \& Seller, 1990, p. 110). The teacher plays the role of facilitator in this type of curriculum metaorientation by stimulating inquiry by asking probing questions. Evaluation focuses on the student's acquisition of complex intellectual frameworks and social skills.

Dewey's theory of education (in books published from 1897 to 1952) serves as a prime example of a transactional curriculum. For Dewey, education, "by employing the scientific method, can help direct the course of social change in a positive direction" (Miller \& Seller, 1990, p. 63).

Rooted in the scientific method, the student moves through a five-step process by: (a) confronting a problematic situation; (b) defining exactly what the problem is; (c) clarifying the problem through analysis; (d) developing hypotheses; and (e) selecting one hypothesis and implementing it. This method, which Dewey (1931) labeled the "'project,' 'problem' or 'situation,' was to serve as an alternative "to organization of courses on the basis of adherence to traditional divisions and classifications of knowledge" (p. 30). Dewey wrote:

There cannot be a problem that is not a problem of something, nor a project that does not involve doing something is a way which demands inquiry into fresh fields of subject matter ... Another feature of the problem method is that activity is exacted ... Within the limits set by capacity and experience this kind of seeking and using, of amassing and organizing, is the process of learning everywhere and at every age. In the third place, while the student with the proper "project" is 
intellectually active, he is also overtly active; he applies, he constructs, he expresses himself in new ways. He puts his knowledge to the test of operation. (pp.33-35)

Dewey believed that education was "the fundamental method of social progress and reform" (1897, "My Pedagogical Creed," Article V). His was a liberal philosophy in that he believed "that in the ideal school we have the reconciliation of individualistic and the institutional ideals"; socialistic because he recognized that "right character is not to be formed merely by individual precept ... but rather by the influence of a certain form or community life upon the individual ... and that the social organism through the school, as its organ, may determine ethical results."

The transformational curriculum has as its context the ecological paradigm in which all phenomena are linked. It is tied psychologically to transpersonal psychology and politically to movements for social change. Its aim is "self-actualization, self-transcendence, [and] social involvement" (Miller \& Seller, 1990, p. 167). Learning experiences focus on the integration of many dimensions, including the physical, cognitive, affective, and spiritual, and on making connections between disciplines, inner and outer realities, and the school and community. Teachers must be in touch with their inner lives, have developed their communication skills, and strive to make links between their classrooms and the larger community. Evaluation is often informal and experimental.

The transformation position, according to Miller and Seller (1990), is represented by two currents of thought, one romantic or humanistic and the other neo-Marxist and concerned with educating for social change. The romantic (or transpersonal) current stresses equality between teacher and child, play and unstructured activity, intrinsic motivation, and a focus on spirituality and the interconnectedness of all reality. Major writers on the romantic current of transformational curriculum include Rogers (1969), Maslow $(1970,1971)$, and Wilber (1983).

The social change position of transformational curriculum is exemplified in the work of Paulo Freire and Henry Giroux, among others. These theorists see curriculum as a locus of conflict, as a site of contestation. Freire's (2001) three-step procedure of consciencisão (consciencization) involves naming important conflicts in a community's situation and "generating interest in these key words," thus enhancing literacy; analyzing the "systemic causes of conflict" in the community; and encouraging "collaborative action to resolve conflicts" (Miller \& Seller, 1990, p. 160). This "pedagogy of the oppressed"

Must be forged with, not for the oppressed (whether individuals or people) in the incessant struggle to regain their humanity. This

pedagogy makes oppression and its causes objects of reflection by the

oppressed, and from that reflection will come their necessary 
engagement in the struggle for their liberation. And in this struggle this pedagogy will be made and remade. (p. 48).

By stressing the integration of the personal and the political, by helping peasants to become conscious of the social, political, and economic roots of their poverty and illiteracy, and by moving students from self-understanding to social involvement, Freire's curriculum is a prime example of a social change transformational curriculum.

In essence, then, emancipatory pedagogy is a pedagogy of social change. Where transaction curriculum is student-centered and stresses individual engagement, transformational pedagogy seeks the transformation of society as a whole, either in an evolutionary (transpersonal) or revolutionary (emancipatory) manner.

According to Giroux (1983), if emancipatory citizenship education

is to be emancipatory it must begin with the assumption that its major aim is not "to fit" students into existing society; instead, its primary purpose must be stimulate their passions, imaginations, and intellects so that they will be moved to challenge political, and economic forces that weigh so heavily upon their lives. (p. 351)

In this article, I use the transmission, transaction, and transformation paradigms to analyze various positions of citizenship education.

\section{Citizenship and Citizenship Education}

Citizenship and citizenship education are highly contested concepts. In a review of citizenship education in public schools in Canada, Sears and Hughes (1996) offer two tables that identify four major conceptions of citizenship and citizenship education. They indicate how ideas about sovereignty, government, and the role of citizens can range from the implicit to the explicit, and how these then inform an equally broad range of ideas about knowledge, values, and skills/participation in citizenship education.

Each conception in Sears and Hughes' (1996) proposed typology "illustrates a view of what constitutes good citizenship and the corresponding knowledge, values, and skills students must learn to be good citizens" (p. 126). Interestingly, Sears and Hughes' models of citizenship education mesh with Miller and Seller's (1990) definitions of curriculum metaorientations.

In Conception A, students are taught a common body of knowledge about the nation's history and political structures. Political and military history are taught in a context of a "narrative of continuous progress" (Sears \& Hughes, 1996, p. 128). Institutions are presented as operating in a lockstep fashion, and teaching styles are traditional. Students are taught a set of national values and the skills needed to vote in an informed manner. This is similar to the characteristics of Miller and Seller's (1990) transmission curriculum, with its focus on facts, concepts, mastery of school subjects, and 
teacher-directed classroom activity. The aim is to reproduce the curriculum as it is from generation to generation.

In Conception B, "students learn the knowledge necessary to become involved in resolving public issues" (Sears \& Hughes, 1990, p. 128). This knowledge is drawn from the liberal arts. Liberal democratic institutions are presented as the best form of social organization in theory, but as flawed in practice. Teaching styles focus on students arriving at alternatives in order to resolve social issues through critical reflective practices and cooperation. This model shares many characteristics with Miller and Seller's (1990) transaction curriculum, with its emphasis on inquiry and problem-solving skills used to facilitate democratic decision-making.

In Conception C, the focus is on preparing citizens of the world. Students are taught about world systems and global topics in order to become committed to ecological responsibility and social justice. They develop critical thinking and cross-cultural skills. In Conception D, a more critical approach is favored. Students are taught that institutions and social structures create oppressive social conditions and to value equality and confront privilege and inequality. These last two conceptions of communitarian citizenship education mirror the two tendencies found in transformational curricula. Conception C mirrors Miller and Seller's (1990) romantic-ecological type of transformation, which stresses the interdependence of phenomena and is linked with self-actualization, mysticism, and worldwide environmental movements, whereas Conception D adopts the social-change position in its emphasis on consciousness-raising and community-based political action.

Although Sears and Hughes (1996) maintain that, at least in their official documentation, citizenship education in public schools in Canada reflects an activist position, Derwing (1992), basing her analysis of 200 responses to a citizenship instruction survey sent to citizenship and/or ESL programs across Canada in 1987 (Derwing \& Munro, 1987), asserts that adult immigrants receive a citizenship education that inculcates passivity. Derwing maintains:

the predominant view [of] ... citizenship is static ... seen as something to be acquired rather than a process of continuous growth in attitudes, skills, and knowledge. The nature of The Citizenship Act serves to encourage a minimal approach to citizenship instruction in that citizenship and ESL programs generally react to the limited knowledge and language criteria stated therein. (p. 193)

In fact, "86 percent of respondents cited preparing students for the [Citizenship] Court hearing as the main objective of their programs" (p. 197). Thus the vast majority of the teachers and administrators in the citizenship and/or ESL programs surveyed by Derwing and Munro (1987) transmitted concepts 
of citizenship as a series of facts to be memorized by students for their citizenship hearings.

It is clear that Derwing (1992) understood citizenship education in the programs she surveyed in 1987 to be based on a transmission (or Conception A) approach to citizenship education. In its place, she calls for a more transactional (or Conception D) curriculum that will stress developing immigrants' inquiry and critical skills. "How we treat citizenship education is a reflection of what we believe citizenship to be. We encourage passivity by denying people the opportunity of developing the knowledge and/or the skills to participate actively in society" (p. 201).

A brief review of the literature of ESL and citizenship courses for immigrants in Canada reveals that many analysts seem biased in Derwing's direction, in being critical of the role of ESL teachers for promoting passive citizenship to immigrants. Bullard's (1989) analysis of citizenship education programs in the 1980s points out that, "by and large, materials and methodologies used in citizenship classes are directed at helping students meet the requirements for naturalization and prepare for their interview with a citizenship judge" (p. 21).

Referring the Derwing and Munro study (1987), Bullard (1989) states that most programs then were "delivered outside the context of ESL, in the form of short-term courses providing information about Canada's geography, history, and political system in order to help applicants meet the knowledge requirements for the citizenship hearing" (p. 24).

It is the development of critical thinking skills among immigrants to Canada, through the use of critical language awareness, that most concerns Morgan (1995/1996). In his article "Promoting and Assessing Critical Language Awareness," Morgan stresses the community basis of many ESL programs in Toronto and believes that a critical community-based ESL pedagogy must include "organizing and assessing second language education around experiences that are immediate to students" (p. 11). Morgan's article is important for highlighting critical language perspective, which he describes as follows.

Dominant social groups ... rely upon the power of language to normalize ways of seeing, knowing, and doing that support their particular interests and privileges. But consent is never a foregone conclusion. Words and texts have many potential meanings ultimately mediated by the particular experiences of the language users ...

Language is used to put people in their place; people also use language to change where they've been placed. (p. 12)

This brief review of the literature points to a tendency among many ESL analysts to disparage much citizenship education for instilling a passive absorption of rote citizenship facts. In contrast, these authors promote the 
use of critical language awareness as a tool for helping immigrants develop critical and reflective problem-solving and cross-cultural skills so that they can participate more effectively as Canadian and world citizens.

\section{A Brief History of LINC and the Canadian Language Benchmarks}

The federal government, in its Immigration Plan for 1991-1995, placed a new emphasis on providing "services at all stages of settlement, from pre-arrival to citizenship," including the creation of the Language Instruction for Newcomers to Canada program (Bettencourt, 2003, p. 25) The provisions of the program were laid out in two documents, Innovations in Training and New Immigrant Language Training Policy, but were later modified in Ontario after consultations with community-based groups from February to June 1992. LINC was established to provide immigrants with basic communication skills, a learning environment that took into account new developments in curricula, teacher orientation, and methodologies (Bettencourt, 2003; Cray, 1997).

The Draft LINC Curriculum Guidelines outline "12 themes, including family life, transportation and Canadian society, for three different levels with tasks, grammar, vocabulary, and pronunciation points that can be taught [as well as] a LINC literacy curriculum" (Cray, 1997, p. 33). The guidelines were designed to meet the needs of students "in a variety of community and institutional settings and to specify content, method, and approach for LINC classes."

In 1997, Revised LINC Curriculum Guidelines (LCRT Consulting, 1997) were published, again for LINC 1 to 3. In the following year, "the Toronto Catholic District School Board [TCDSB] was awarded the contract to develop the curriculum guidelines for LINC 4 and 5 ... to establish measurable outcomes based on the Canadian Language Benchmarks" (TCDSB, 1999, p. 9). The TCDSB published the LINC 4 \& 5 Curriculum Guidelines in 1999.

In 2001, Citizenship and Immigration Canada contacted the TCDSB "to combine the two existing curriculum guidelines for LINC and make them consistent with the Canadian Language Benchmarks 2000" (Witol, 2004, p. 15). The result, the LINC 1-5 Curriculum Guidelines, were published in 2002.

This article is concerned with the LINC 4 \& 5 Curriculum Guidelines (TCDSB, 1999) because it was the guideline document used by the participants in this study when they worked as LINC teachers. Furthermore, initial access to one of the two members of the Expert or Advisory Committees involved in the planning of these guidelines allowed me to investigate this curriculum document from its planning stages through to its subsequent use by these teachers. 


\section{The Canadian Language Benchmarks}

Although LINC provides a specific curriculum for teachers in this language and settlement program, it is the Canadian Language Benchmarks that are used to assess the language level of immigrants across English-speaking Canada so that they can be placed in appropriate LINC class levels.

The first assessment tool used with LINC was A-LINC, developed at Vancouver Community College in 1992 (Bettencourt, 2003). In 1992, Employment and Immigration Canada

funded a project to develop national standards, beginning with consultations with experts in second language teaching and training, testing and measurement. The consultations confirmed that no one instrument, tool or set of "benchmarks" was widely used or appropriate to Canadian newcomers' needs. (Pawlikowska-Smith, 2000, p. vi)

In March 1993, the National Working Group on Language Benchmarks (NWGLB) was established by Citizenship and Immigration Canada. This group published the first version of the Canadian Language Benchmarks in 1996. A revised version, Canadian Language Benchmarks 2000, followed.

The Benchmarks are

a descriptive scale of communicative proficiency in English as a Second Language (ESL) expressed as 12 benchmarks or reference points; a set of descriptive statements about successive levels of achievement on the continuum of ESL performance; [and] statements (descriptions) of communicative competencies and performance tasks in which the learner demonstrates application of language knowledge (competence) and skill. (Pawlikowska-Smith, 2000, p. viii)

The Benchmarks are used by assessors in LINC assessment centers to place immigrant students in the proper LINC level.

In the following section, I analyze how various concepts of citizenship and citizenship education inform the LINC $4 \mathcal{E} 5$ Curriculum Guidelines through three stages: in its production, reception, and implementation.

\section{The LINC 4 \& 5 Curriculum Guidelines: The Production Stage}

In "The Practical: Translation into Curriculum," Schwab (1973) outlines a deliberative form of curriculum planning in which representatives from five disciplines - the subject matter, the learners, the milieus, the teachers, and the curriculum specialist-collaborate with one another through a twophase process. In the first phase, these representatives or "agents of translation" go through a three-step program of discovery, coalescence, and utilization, to generate "new educational materials and purposes" (p. 501). 
Each representative is to be treated as an equal participant in the collaborative process, in order to discover the experiences of others and for a coalescence to occur of these bodies of experience in the curriculum-making process. The curriculum specialist must not seek to overawe the group, but rather should serve three functions: first, in the preliminary or discovery phase, to remind the group of the importance of the experience of each representative; second, in the writing or coalescence stage, to administer the process of the realization of the curriculum; and third, in the revision or utilization stage, through the trial use and reworking of this curriculum.

The creation of the curriculum guidelines for LINC $4 \& 5$ appears to have followed Schwab's (1973) deliberative model. In the development of the Guidelines, there were three committees, the Guidelines Advisory Committee, the Guidelines Expert Panel, and the Ontario Region LINC Advisory Committee (ORLAC), which reacted to the curriculum at various stages. As well, piloting of the guidelines was done with various groups of teachers and a survey taken of LINC teachers who had used the Guidelines.

Thus representatives of the five disciplines mentioned by Schwab (1973) were involved in this curriculum-making project: the subject matter (English-as-a-second-language and settlement issues) through specialist advisers, the learners (the immigrant students), the milieus (cultural advisors, schools, school boards), and the teachers (through field testing, questionnaires, and workshops).

Comments by two informants, members of the Expert or Advisory Committees, highlight the fact that the process of making the LINC $4 \mathcal{E} 5 \mathrm{Cur}$ riculum Guidelines was one of contestation as well as compromise. One informant stated,

There was considerable debate around the issue of technology in the Guidelines (important for integration into Canadian society) the organization of the material in the Guidelines to offer the teachers that maximum amount of flexibility-organizing the material around themes with the material for LINC levels $1-5$ being inserted consecutively rather than all the material for the 12 themes at each LINC level being presented separately.

Whereas this informant raised concerns about the role of technology, teacher flexibility, and the ordering of the thematic material in the Guidelines, the other's concerns focused on some of the difficulties involved in trying to deal with two related issues-form-based instruction and content-based instruction-while also trying to provide for the possibility of a more critical citizenship pedagogy given the constraints imposed on it by the LINC 1-3 guidelines and the task-based Canadian Language Benchmarks.

According to this second informant, the Canadian Language Benchmarks are underpinned by two theoretical components, Krashen's acquisitional 
model of language learning and Nunan's framework for task-based learning. For Nunan (1989),

A communicative task is a "piece of classroom work involves learners in comprehending, manipulating, producing, or interacting in the target language while the attention is principally focused on meaning rather than form. The task should also have a sense of completeness, being able to stand alone as a communicative act in its own right." (Fox \& Courchêne, 2005, p. 7)

This informant's goal was to justify theoretically the introduction of preand post-tasks into the curriculum, in order to "move towards explicit ... grammatical and pronunciation components" and thus legitimize what many ESL instructors had already been doing with their immigrant students. As well, this informant was concerned with focusing on content in a more critical way in each of the thematic components. This was highlighted in a discussion about the theme of banking.

Banking can mean two things, you know: are banks ethical or moral, or how do I open a banking account? And I worked very hard to make sure that both elements were in the units. I said, "Let's do banking, but one of the topics is going to be what are the ethical limits of ... bankers. Is it moral, what they're doing?" And stick that in there right beside how do I open a checking account ... That we don't take things at face value. That we look at every topic and unit from both sides.

In terms of the curriculum metaorientations, this informant's efforts can be seen in the framework of attempting to include more transactional aims and learning experiences in a curriculum document the antecedents of which had tended to stress the transmission approach of survival English, focusing on facts and concepts required by immigrants for their citizenship interviews.

Exception was also taken by this informant in how the Canadian Language Benchmarks equate students' abilities to analyze complex social issues with their abilities to communicate and analyze opinions.

One of the things I tried to talk about ... [was] how, even at a basic level, people will engage with the substance of these topics, but they will frame them in everyday experience ... It's an elitist attitude, when the curriculum's like that. When they get to Level 12 and they can manipulate this highly complex sentence structure, then they can talk about human rights, or the Canadian political system which, you know, I think is nonsense. And I used to complain bitterly to people in the writing of documents that this doesn't need to be that way.

Critical citizenship was characterized as involving "a kind of critical autonomy ... the ability to not take things at face value, to appraise and 
evaluate ... To be able to weigh the consequences and to see whose interests are being served behind anything and whose are not." Although admitting that some of the themes could not be developed in the Guidelines given the restrictions imposed on the team by the Canadian Language Benchmarks, this informant is still pleased that the document does provide LINC teachers with possibilities for critical engagement about citizenship.

I think that there [are] really positive aspects of the document. Just the fact that they are there encourages teachers ... the fact that it's there allows teachers who feel they want to do that kind of teaching, who are inspired by it ... [to be] legitimated to do it ... I think it's a great document and, for those people who want to build on it, I think the basic tools are there.

This informant's analysis of the curriculum development process of the LINC 4 \& 5 Curriculum Guidelines reveals that deliberation did take place, during which a range of opinions about both more explicit language teaching as well as various conceptions of citizenship and citizenship education were presented and discussed.

\section{The LINC 4 \& 5 Curriculum Guidelines: Reception-The Written Form}

A note from the Guidelines serves as an apologia to those seeking content geared toward a more critical approach to citizenship education and lays the responsibility for its lack on the task-based focus of the Canadian Language Benchmarks.

Using the Canadian Language Benchmarks to develop these curriculum guidelines imposes certain limitations. Competencies that may be more suitable to particular topics could not be used because they do not correspond to the Benchmarks assigned to LINC 4 and 5. For example, International Human Rights, Native Peoples and National Unity do not lend themselves easily to the pragmatic, functional competencies described in the CLB at these levels and are more suited to competencies such as critical analysis (Reading, Benchmark 9) or expressing and analyzing opinions (Listening/Speaking, Benchmark 8). Consequently, these topics may not have been addressed as profoundly as the issues warrant but were included anyway because learners expressed an interest in them. (TDCSB, 1999, p. 10)

The Guidelines present 12 themes, each divided into three parts: Business, Canada, Canadian Culture and Society, Canadian Law, Community and Government Services, Education, Employment, Finance and Banking, Global Issues, Health and Safety, Relationships, and Travel and Tourism (TCDSB, 
1999). Analysis reveals that sample language tasks do range, on occasion, from the pragmatic to the more critical. For example, under Canada-Government, topic outcomes include the ability of students to "describe systems of government in Canada and other countries" as well as to "agree, disagree with current government policies" (p. 35). The topic Canada-Native Peoples has as an outcome to "relate a story about a famous Native Canadi$\mathrm{an}^{\prime}$ (p. 37), and a suggestion is also made that "Classes might want to learn about recent court cases involving Native claims to ancestral lands and natural resources" (p. 36). Other critical aspects of the text either in terms of suggestions, topic outcomes, or sample language tasks include writing "a short text about [students'] own experience with Canada's multicultural society" (Canadian Culture and Society-Cultural Diversity, p. 39); "legal definitions of child abuse; legal requirements to report child abuse ... legal supports for women who are victims of domestic violence; the legal rights of same-sex couples" (Canadian Law-Family Law, p. 46); "barriers to employment for immigrants; discriminatory practices by professional organizations" (Employment-Skills Assessment, p. 66); and "the social and ethical responsibility of banks and government regulatory bodies; the implications of bank mergers" (Finance and Banking, p. 68) are a few instances.

\section{The LINC 4 \& 5 Curriculum Guidelines: \\ Implementation-The Curriculum-in-Use}

\section{Participants}

Besides the two informants from the Expert or Advisory Committees, I also interviewed five present or former LINC teachers with whom I was working or had already worked, one man and four women with a total of 58.5 years' teaching experience among them (or over 10 years' experience each, on average). Three of the five had taught adults exclusively for school boards and in colleges in the Toronto area, as well as for a Toronto-area college with an arrangement to take students from China. Besides teaching LINC 1, 3, 4, and 5, these teachers had also taught adult ESL in the Labour Market Language Training program, in a Toronto-area school board program, English for Academic Purposes, as well as French and Italian. One of the teachers had spent each alternate school year teaching kindergarten to grade 6 in a public school.

\section{Study}

Within institutional guidelines for free and informed consent, I interviewed the participants between October and December 2002 in various settings. Interviews were audiotaped and then transcribed. In the interviews, I focused on how each participant dealt with what he or she considered the more controversial themes or his or her more controversial duties in LINC. It 
was here especially that the demarcation between those who favoured a mixed transmission/transactional approach, a mixed transactional/transformational approach, or a purely transformational approach became more readily apparent.

\section{Data and Findings}

Transmission pedagogy. None of the participants followed a "pure" transmission approach to curriculum.

Transmission/transaction pedagogy. Three of the five teachers interviewed felt comfortable teaching practical themes. As one teacher explained, "I feel more comfortable teaching the themes that I thought they would use, such as shopping ... [or] health care services." Another voiced similar sentiments when she noted, "In level 4 and 5, it was also very functional, so we taught things about buying and selling, negotiating things, on top of the regular housing in Canada and all that regular citizenship stuff." A third mentioned how his students considered information related to Canada important.

Because when you teach Canada, they perceive that, in a way, as an academic thing. Or it's very clear to them that they have to amass some kind of information about this new country. Also, that's a very varied topic, since you're teaching this province, geography, history. So I think they enjoy that.

Teachers mentioned that they tailored their classes to meet the majority of their students interests, as one class may be made up primarily of adult immigrants who have been professionals in their country and are interested in getting a Canadian job as quickly as possible, to either older people or housewives who are not looking to work, but rather come to class for social and academic reasons. As one teacher mentioned,

I think looking for work, Canadian culture and geography [were popular] ... Those are the main ones ... Because, in one class, I had a lot of professionals, and they all wanted to go out and work. I had engineers ... You know, I accommodated it to the class. The other class I had, the 4 high, were only interested in just studying a little bit of geography - a lot of women that weren't working and didn't intend to work. So just general knowledge ... You know, different levels of government, different newspapers we have to read, what the climate is like here, how many provinces we have. All that kind of stuff.

These teachers taught practical topics using a more transmission-oriented pedagogy, often centered around form-based grammatical points.

So ... I would model the grammar point, and then I would try to use authentic materials from the community that had the structure. So I would get maybe brochures from the Canadian Human Resources 
Centre and we would look at the grammar structure there, or we would look at sample interviews. That, to me, was the most important ... that LINC was authentic material, because they [students] would have to use these materials and if they could see the structure, then they might be able to use it.

Other authentic activities these participants mentioned using included having students fill out forms, write résumés, and role-play job interviews.

Conversely, when faced with teaching a more controversial topic, such as women's rights or same-sex issues, most participants seemed to react by ignoring the topic completely or else by allowing students a limited amount of time for a values' clarification discussion. The topic that made three of the teachers the most uncomfortable was same-sex issues. Two avoided the issue altogether. As one explained, "Same-sex benefits and things like that, I strongly believe in, but with quite a few Muslim students, any mention of topics like that made the women very uncomfortable." Creating a nurturing environment was important to this teacher, and controversial topics that might divide the class were best not debated, because "I just didn't want them [students] to be uncomfortable. I wanted them to feel they could come and learn and not justify their religious views and things like that."

A second participant seemed to have mixed feelings about not wanting to confront a controversial topic like homosexuality. She likened dealing with cross-cultural sensitivities to walking a tightrope because, "You have to be careful. You don't want to offend people, but, at the same time, you know, you want ... to keep them interested in learning. That's why they're there."

At the same time, this teacher became intrigued by a colleague's willingness to discuss this issue with her students. Visiting her colleague, this participant found vocabulary about homosexuality on the board and asked this teacher how she had broached the subject.

And she said, "Oh, yeah. I'm talking about differences in the family and what we accept." And there was something else she did ... some vocabulary ... She did much more than me, in that. And that's when I started to think, "I never thought about that."

Thus this teacher became aware of new pedagogical ways to broach delicate subjects in a multicultural classroom.

Two participants defused the same-sex issue by resorting to a legal interpretation of rights for homosexuals in the framework of Canada's liberaldemocratic system. This exemplifies Sears and Hughes's (1999) Conception A of citizenship education, in that teachers teach "a particular set of national values." One teacher expressed the view that although everyone was entitled to his or her opinion on the subject, in the end, "It doesn't matter who you are or what you are, the law says this. And this is the way it should be." Another 
revealed that she would say, "that I could understand where they were coming from, but, you know, now they are in Canada."

A more transactional response to the topic of women's rights saw some participants pose Socratic questions or engender small-group discussions in order to generate values clarification among their students. The participant who did not deal with homosexuality did deal with women's issues as "a positive, not as a negative, as in: 'We've done this ... and this is what happens in other countries.'" Faced with a male student's misogynistic claim that "women aren't smart," this participant asked questions, "so that they would be able to debate back and forth. Or explain their justification ... The right questions ... will elicit responses from them and get them to think, you know, 'What if? What if?'" Another male participant responded to the views expressed by a group of Middle Eastern male students about women by encouraging discussion. These men believed that their culture protected women, "because women were all covered up in the traditional dress and protected by the family and [could not] walk in public," whereas "we put half-naked women all over advertisements, and I think they mentioned the porn industry." This participant continued,

I think I discussed it with them, that this was news to me, that, actually, somebody sees what happens in the Arabic world and what we

perceive as repression ... they perceive as protection. And I didn't just

discard the idea. I thought, "Hum, this is something to think about!"

In the end this teacher agreed with the men about the fact that sexual exploitation of women existed in the West, but suggested that other movements existed at the same time that were trying to change the situation. "I didn't defend our culture," this participant went on, "as the ultimate and superior and totally perfect, all the problems have been solved ... I admitted that yeah, we have both [situations] here, I guess. And we're working on it."

This approach, of admitting to how Western society fell short of its own ideals, is reminiscent of Sears and Hughes' (1990) Conception B of citizenship education, because in this instance, liberal democracy was "presented as the best theoretical form of social organization but as flawed in practice" (p. 128).

\section{Transformational Pedagogy}

Only one of the five teachers interviewed used the Guidelines as part of a transformational pedagogy in an effort to promote "self-actualization, selftranscendence, [and] social involvement" (Miller \& Seller, 1990, p. 167). This participant had been involved in the LINC program since one year after its inception in 1992 and had taught some LINC 2, but mainly LINC high 3 classes, which she believed was equivalent to a low LINC 4 class in that, "You can take any subject that is in LINC 4 or 5 curriculum and teach it to the LINC 3 high." 
The Guidelines themes this teacher used consistently were "human rights, job search, the law in Ontario and education issues in Ontario," but it is in her combination and critical use of these themes that this participant's pedagogy can be understood as transformational. She connects "human rights and ... workers' rights to any kind of employment stuff they are going to do" in order to expose her students to some of the hidden discriminatory practices at play,

because a lot of our students believe that there is no racism, that there is no sexism, that these things exist somewhere, but it's not going to affect them. So I bring in some of the ideas, not to frighten them and I tell

them that, "I hope I haven't upset your world, but I want you to know that this exists, and this is how it works."

As an example, she mentioned distributing newspaper stories dealing with various discriminatory situations. One dealt with a major electronics chain's policy of not promoting nonwhites to management positions, an attempt by three white managers to change the head office's policy, the company's firing of one of the managers, and this manager's subsequent challenge before the Ontario Human Rights Tribunal. The students moved from learning about a local company, "a company they would patronize" and its racist promotional policy, to the fact that "management became responsible to the workers and to each other for what was going on." Next, through simplified authentic material, students studied the Ontario Human Rights Code. Then students were asked if they had experienced these kinds of things in their own countries. They began "by totally denying" it. Later, students were asked to identify a situation that they or someone they knew had experienced when they first arrived in Canada that they had not realized had been a form of discrimination at the time. The students were then encouraged to write about this, then give an oral or dramatic presentation, which involved "all the competencies." Students then offered peer reviews of these presentations based on pronunciation and other discrete items.

This participant believed strongly that

the settlement part of the LINC program has to be confrontational and heads-on. I think you need to show people that what they're facing is real. It's not in their heads. It's not just because they've just gotten here. It may go on for years.

At the same time, she also believed that a lot of LINC teachers "pussy-foot around the negative, and I think that is unfair and it's not giving these people a fair chance" to deal with the systemic forms of racism and sexism they face as immigrants to Canada. 
This participant's form of transformative pedagogy is closely related to Sears and Hughes' (1996) Conception D of citizenship education, which stressed consciousness-raising and community-based political action.

\section{Limitations of the Study}

Although I have sought to analyze the concepts of citizenship that have informed the making, final form, and implementation of the LINC 4 E 5 Curriculum Guidelines, I would be remiss not to acknowledge certain limitations to my study. For example, although I was fortunate in being able to interview one informant and receive feedback from another, both of whom had been members of Expert or Curriculum Guideline Committees, my study would have benefited from input from other members of the Expert Panel, the Curriculum Guidelines Advisory Committee, teachers' groups, or the writing team. This would have helped create triangulation and a clearer sense of the contestation around citizenship on these committees. Also, my study could be faulted for being based on interviews with five teachers who are, or have been, my colleagues in various schools in the Toronto area.

\section{Conclusion}

This article highlights how citizenship and citizenship education are sites of contestation. Although the LINC document analyzed here can be characterized as representing a liberal democratic approach to citizenship and a transactional approach to citizenship education in a multicultural framework, a minority position supporting a more critical and transformational approach to citizenship education is also evident.

Unlike Derwing's (1992) findings in which teachers stressed that their main function was to aid adult immigrants pass their Citizenship Test, these teachers' objectives tended to center on teaching students about Canada and wanting to help them participate in Canadian society and improve their English. What varied among the participants in this group was the type of participation the teachers' envisaged for their students. Most wished to aid them in their settlement process so that they might become citizens active in Canadian society; at least one envisaged her students being both socially active and critically aware.

Although this work, like many qualitative studies, deals with only a small group of participants, I believe it can help shed light on how curriculummaking and use are processes of contestation and adaptation. As well, I hope it will encourage LINC teachers to develop a critical perspective on their practice with their immigrant students, especially in the context of the struggles, both emotional and financial, that these individuals face. 


\section{Acknowledgment}

The author thanks Brian Morgan for reading and providing valuable commentary on earlier versions of this work, as well as the two anonymous readers who reviewed the manuscript for the TESL Canadd Journal.

\section{The Author}

Robert Pinet teaches ESL writing courses at Humber College in Toronto and is a doctoral student in Curriculum, Teaching and Learning/Comparative, International and Development Education at the Ontario Institute for Studies in Education of the University of Toronto.

\section{References}

Bettencourt, E. (2003). LINC then and now: 10-year anniversary. Contact, 29(2), 25-28.

Bobbitt, F. (1924). How to make a curriculum. Boston, MA: Houghton Mifflin.

Bullard, J. (1989). Citizenship education: A trivial pursuit? TESL Talk, 19(1), 19-28.

Centre for Language Training and Assessment 9CLTA). (2004). Guidelines for LINC assessment centres in Ontario. Mississauga, ON: Author.

Cleghorn, L. (2000). Valuing English: An ethnography of a federal language training program for adult immigrants. Unpublished master's thesis, University of Toronto.

Cray, E. (1997). Teachers' perceptions of a language policy: “Teaching LINC.” TESL Canada Journal, 15(1), 22-37.

Derwing, T.M. (1992). Instilling a passive voice: Citizenship instruction in Canada. In B. Burnaby \& A. Cumming (Eds.), Socio-political aspects of ESL (pp. 193-202). Toronto, ON: OISE Press.

Derwing, T.M., \& Munro, M. (1987). Citizenship preparation in Canada: An overview. TESL Talk, 19(1), 35-41.

Dewey, J. (1897). My pedagogical creed. School Journal, 44(3), 77-80. [Electronic version] Retrieved September 24, 2005, from: http://www.infed.org/archives/e-texts/e-dew-pc.htm

Dewey, J. (1931). The way out of educational confusion (the Inglish Lecture). Wesport, CT: Greenwood Press.

Fox, J., \& Courchêne, R. (2005). The Canadian Language Benchmarks (CLB): A critical appraisal. Contact, 31(2), 5-26.

Freire, P. (2001). Pedagogy of the oppressed (30th anniversary edition). New York: Continuum.

Giroux, H. (1983). Critical theory and rationality in citizenship education. In H. Giroux \& D. Purpel (Eds.), The hidden curriculum and moral education: Deception or discovery? (pp. 321-360) Berkeley, CA: McCutchan.

Maslow, A. (1970). Motivation and personality. New York: Harper \& Row.

Maslow, A. (1971). The farther reaches of human nature. New York: Viking.

Miller, J.P., \& Seller, W. (1990). Curriculum: Perspectives and practice. Toronto, ON: Copp Clark Pitman.

Morgan, B. (1995/1996). Promoting and assessing critical language awareness. TESOL Journal, 2(2), 13-17.

Pawlikoswka-Smith, G. (2000). Canadian language benchmarks 2000: English as a second language-For adults. Ottawa, ON: Citizenship and Immigration Canada.

Richardson, A.S. (1999). Ideologically speaking: Teacher conversations about practice in relation to the program mandate for LINC, Language Instruction for Newcomers to Canada. Unpublished master's thesis, Simon Fraser University.

Rogers, C. (1969). Freedom to learn. Columbus, OH: Merrill.

Sears, A.M., \& Hughes, A.S. (1996). Citizenship education and current educational reform. Canadian Journal of Education, 21(2), 123-142.

Schwab, J. (1973). The practical: Translation into curriculum. School Review, August, 501-522. 
Thomson, R., \& Derwing, T.M. (2004). Presenting Canadian values in LINC: The role of textbooks and teachers. TESL Canada Journal 21(2), 17-33.

Toronto Catholic District School Board (TCDSB). (1999). The LINC 4 \& 5 curriculum guidelines: A computer-integrated curriculum based on Canadian language benchmarks 4-6. Toronto, $\mathrm{ON}$ : Author.

Wilber, K. (1983). A sociable god. New York: McGraw-Hill.

Witol, P. (2004). Incorporating competency-based Canadian Language Benchmarks into a theme-based curriculum. Contact, 30(2), 15-22. 